\title{
Small, Slow and Shared: Emerging Social Innovations in Urban Australian Foodscapes
}

\author{
Ferne Edwards
}

\begin{abstract}
Bring your surplus home grown fruit, vegies, herbs, food/plant seeds, seedlings, eggs, honey, jams and preserves and swap your produce with other local home producers! ('Bacchus')

Grab your spades and gloves, get sweaty, have fun, learn lots and feel all warm and fuzzy afterwards! ... ('Events')
\end{abstract}

The quotes above, drawn from alternative food networks that are based in major Australian cities, optimistically call for participation in produce and growing 'swaps'. They do so in the belief that such exchanges will promote greater food security, sustainability and community resilience in cities. Other enticements include: 'We are different-in a good way! Great tasting local produce, as fresh as can be, we play fair with our farmers, we use way less packaging...' (Foodconnect). These more urban-based, fresh food initiatives represent an emerging alternative to 'You don't have to go to a supermarket - woo hoo!' (Foodconnect). ${ }^{1}$

New social practices based around food are emerging as a response to many uncertainties and contradictions evident within the current industrial food system. Critical changes in economic, political and environmental conditions over the last few years have challenged the sustainability and security of the world's food supplies. Australia is not insulated from the impacts of these global changes, suffering from climate change and increased agricultural costs, contributing in part to health impacts such as obesity and food poverty (Edwards, Larsen and Ryan). Economic and social inequalities present within the global food chain are further expressed in Australia due to the concentration of power held by the national supermarket duopoly.

As a reaction to the vulnerabilities of the dominant neoliberal food system based on industrialisation, privatisation, deregulation, standardisation and commodification, there are a growing number of informal, localised and community-based social practices based around food appearing in Australian cities. These new producer-consumers go beyond green consumerist,

$1<$ http://brisbane.foodconnect.com.au>. Accessed 26 October 2011. 
supermarket-purchased certified organic, Fair Trade, and Australian-made choices and extend from the community garden model to suggest new ways of engaging with food. Grassroots initiatives are driven predominantly by social and ecological concerns and tackle associated issues arising along the food chain, carving new spaces into urban territories. Building on urban food practices of the past, these innovations represent a formalisation of noncommercial food exchange and distribution networks, many of which engage emerging digital technologies to extend beyond the personal. The number and diversity of models emerging within the city promotes social, environmental and economic resilience, while engaging a wide audience. Although seemingly meagre set against the sheer scale of the formal economy, these pockets of change reveal patterns of community understanding and concern. They also represent a creative source of ideas on the edge that provide potential food system innovation. Furthermore, this groundswell of social action is constantly changing and growing.

This paper focuses on the emergence of this new wave of urban, local food practices in the city of Melbourne in 2008. It builds on food mapping research conducted at the Victorian Eco-Innovation Lab (VEIL) involving a broad literature review spanning commercial and community food enterprise sources including organic food directories, newspaper articles, community and environmental websites and newsletters. This initial food mapping research contributed to a Briefing Paper (Edwards, Larsen and Ryan), informed the VEIL Food map (http://www.ecoinnovationlab.com/veil-food-map/96-veil-food-map), an online repository of garden sites, and was further extended by student participation in the RMIT University subject, 'Meals in Metropolis' (Edwards and Mercer). This research reveals but a brief snapshot of the diversity and richness of this emerging grassroots movement that would benefit in time from more in-depth research to analyse its overall outcomes. While these food activities are based in Melbourne, they are also translatable to other Australian and global cities where food has once again become a central focus for community engagement, expression and action.

The paper is structured in three parts: 1) a brief historical context and overview of emerging grassroots food practices in Melbourne; 2) a discussion of three case study organisations, Permablitz, Urban Orchard, and Food Connect, and their key characteristics of small, slow and shared; and 3) future food possibilities. The research contributes to Alternative Food Network theory by recognising the social and political significance of the often-overlooked informal, noncapitalist and non-commodified alternative food networks. 


\section{Mapping Melbourne's food movement- from past to present}

\section{The tides of domestic food production in Melbourne}

Melbourne was pronounced an official settlement in 1837, offering an excellent site for food production with fertile soils located in a temperate zone with an adequate water supply. This site that once provided, and still continues to provide, many indigenous foods (see Gott and Conran; Sola and Gott) became, by the year 1881, stocked with livestock and poultry in both Melbourne's outer and inner urban suburbs, ${ }^{2}$ part-providing for milk, eggs, vegetables and fruits on a house-hold scale (Barrett). Increased interest in local food growing, in the period leading up to World War I, was due to a general lack of capital investment in property and infrastructure requiring residents to provide for themselves (Mullins). A food supply deficit occurred during World War II resulting from the additional need to provide for the troops, prompting a nationwide 'Grow Your Own' campaign. Food was produced in the domestic sphere in urban centres similar to the Victory Garden movement in wartime Britain (Hujber), and commercial food industries grew in peri-urban Melbourne.

The postwar era saw the rise of multinational corporations as supermarkets promoting mass-produced items negated the need for domestic production (Mullins). 'Low maintenance' gardens became popular in the 1950s with reduced vegetable beds, while fruit trees, compost and large animals moved out to rural regions. Many theorists contend that the backyard shifted from a site of production (utilitarian) to consumption (recreation use), as the vegetable patch and chicken coop were removed to make way for the chlorinated swimming pool. However, as Gaynor attests, food production never completely disappeared from the suburbs, and instead persisted, hidden away in backyards, practiced predominantly by people who valued food production for more than primary economic reasons.

The 1960s and 70s brought immigrants from southern Europe and their cultural gardening practices to Melbourne. Their enthusiasm for gardening is represented by $34 \%$ of Italian-born citizens keeping chickens compared to $7 \%$ of Australianborn residents (Halkett). The emergence of the environmental movement in the 1970s encouraged greater domestic food production for purposes of self-reliance and independence, with residents wishing to reduce their involvement in a wasteful global system. Such a trend in Australia emulated aspects of the 1968

$240 \%$ of outer urban residents owned large livestock and $63 \%$ owned poultry; $8 \%$ of inner urban residents owned livestock and $21 \%$ poultry (Barrett). 
'right to the city' movement in France, as expressed in Henri Lefebvre's book of the same title. This movement called for an inclusive and transformative political re-imagining of how, and for whom, cities might work, no doubt reuniting the role of cities and food production in a bid to the right to sustainability (Patel).

However, in more recent years, both urban and peri-urban food production declined significantly in Melbourne due to the increasing power of supermarkets, the climatic effects of drought, the population and planning impacts of urban densification and peri-urban sprawl, and due to socio-economic conditions of rising house prices and everyday financial pressures (Buxton et al.; Gaynor; Low Choy et al.). However, productive remnants remain: it is still possible to 'pick-your-own' strawberries, blueberries and cherries, to find market gardens producing commercial vegetables, to locate chicken hatcheries and egg laying industries, and to sight transitory beekeepers in Melbourne's peri-urban zones, while lemon trees and passion fruit vines perch above or over fences in urban streets.

There has also been a shift, in recent years, whereby some enterprises are now located within city boundaries, as environmentally-friendly producers seek to reduce transport costs and take advantage of the city's access to water, labour, energy and markets. Examples include Mountain Goat Brewery, which produces beer in inner urban Richmond and incorporates passive heating, wind turbines, solar panels, water tanks and wastewater treatment processes; Melbourne's numerous farmers' markets, that have recently expanded in number and size and create direct links between Victorian farmers and city consumers; and Tiffins Caterers and Catering Service which 'tricycles' freshly cooked curries to city diners. The Melbourne-based, not-for-profit food organisations, FareShare, SecondBite and VicRelief FoodBank, also take advantage of the city's resources to address social justice, environmental and corporate social responsibility concerns by redistributing, to charity organisation and others in need, still-edible food that is no longer commercially viable from open markets, supermarkets, airlines, restaurants and hospitals..

These commercial and not-for-profit food initiatives illustrate alternative, innovative, divergent forms of capitalism that maintain neoliberal politicaleconomic relationships. However, there are also grassroots social practices emerging in Melbourne that represent a further unexpected turn in food gardening and that demonstrate the growth of non-capitalist and noncommodified practices. Often overlooked as insignificant and invisible hobbies, these emerging urban food practices build on past knowledge to make productive potential of local resources. Such practices suggest some of the ways that new enterprises, based on older models, develop in a way that responds to the needs of growing cities and urban concerns, while engaging with accessible new technologies that move local production beyond the 'backyard'. These 
initiatives form one strand of Alternative Food Networks (AFNs). This research contributes to AFN literature in general, and more specifically to food research currently conducted within Australia (Hujber; Gaynor; Head and Muir; Holmes, Martin and Mirmohamadi).

\section{Consumer becomes producer-I eat what I sow}

Melbourne's citizens are responding to local and international concerns by growing more food either on their own land, communally with neighbours and friends, or in public plots, while others simply pull down their fences to maximise space, extending their vegetable patch onto footpaths or parklands. Guerrilla gardening provides a more radical approach whereby people repossess underused public space to grow food. Evidence of an increase of gardens and growers in Melbourne is revealed by a rise in the number of food-related resources, services (or advocacy for these), conferences, programs, projects and plots. In 2009, the Australian television current affairs show Sixty Minutes reported on the groundswell of the 'backyard revolution', while local newspaper Northcote Leader reported that chook food sales were at their highest in a Thornbury shop's forty year history (Gallagher). Further, the advocacy group, The Food Gardeners' Alliance, established in 2007, represents home gardeners, horticulturalists and landscape designers and lobbies government for more suitable water allocations for food gardens. New services to support people growing their own include Permablitz (http://www.permablitz.net), informal gatherings where volunteers come together to create food-producing gardens; and the local business Book A Chook (http://www.bookachook.com/) that 'rents' chickens to householders to encourage keeping poultry in urban areas.

People who grow their own food often want to better understand and control their food production to ensure access to a healthy, affordable supply. Food scares are often associated with intensive, industrial production where the origins, contents and processes of food manufacturing are difficult to ascertain, and hence, control (Pollan; Crittenden ). By growing their own, citizens take back control over what they eat. Of course, many people often enjoy gardening too-according to Hujber, Melbourne gardeners' main motivation is pleasure to be gained from growing (and eating) fresh, tasty produce, with health, environmental and community involvement as equal seconds, and economic reasons as an insubstantial third.

Many organisations also use food to unify related issues, such as ownership, community and responsibility. The social networking site Grow Local connects food producers expressing the need to 'foster relationships that are not based on want' (http://www.growlocal.net.au/). The Victorian Department of Human Services 'Victoria in Bloom' Award emphasises the importance of food gardening 
to the building of vibrant communities (http://www.housing.vic.gov.au/livingin-housing/getting-involved/victoria-in-bloom-garden-competition), and the community garden Sprout (http://www.mindaustralia.org.au/Sprout.htm) serves as a social support space for people with psychiatric disabilities, drug or alcohol issues or at risk of homelessness. VicHealth's 'Food for All: Improving Access to Food for Healthy Eating' program unites health with urban planning and community engagement, supporting local councils to increase food security (http://www.vichealth.vic.gov.au/en/Publications/Healthy-Eating/HealthyEating-Programs/How-local-government-is-improving-access-to-nutritiousfood.aspx). Also important are schools that recognise the multiple benefits of food production and that educate children about nature, the food system, cooking and healthy diets. Melbourne has a plethora of popular school kitchen garden projects run by the Stephanie Alexander Kitchen Garden National Program, Cultivating Community, CERES (Centre for Education and Research in Environmental Strategies), the Gould Group, and by independent schools.

\section{Producer becomes distributor: I share what I grow}

As people grow more food, they also create new ways to redistribute surplus. Many redistribution schemes exist at the community level and never enter the commercial sphere. Popular Melbourne-based, food-surplus-swap models include Urban Orchard, Moreland Community Health Service's 'Grow and Share' project, and the proposed Pedalling Fruit Pickers' project. At Urban Orchard, people exchange surplus food grown in their own backyards (http://www.ceres. org.au/node/114); 'Grow and Share' targets the disadvantaged community by teaching how to grow specific foods to be shared (Moreland Community Health Service); while Pedalling Fruit Pickers aims to harvest and collect unwanted crops from residential properties to redistribute to the community (Environment Victoria). These informal exchanges differ past food exchange practices as they aim to reach broader community members. At the same time, surplus produce is now able to be freely redistributed through online technologies, such as through the Melbourne-based GrowLocal and the Australia-wide Home Growers' Exchange (http://homegrowers.ning.com/). These online networks often complement rather than replace face-to-face exchanges and provide avenues for socially isolated individuals to participate. Although not yet officially based in Australia, 'backyard sharing' 'encourages urban gardening by connecting those who have space to garden and are willing to share with those who would like to have a gardening space' (Hayes). ${ }^{3}$

3 Landshare Australia, an online service that links growers to people with land to share, was launched in Australia in 2011 (see <http://www.landshareaustralia.com.au>). Accessed 26 October 2011. 


\section{Small, slow and shared}

From this brief history, it is apparent that alternative methods of food production and distribution in Melbourne have not disappeared but are instead re-emerging, using new technologies while formalising new models of civic engagement. A key characteristic of this new wave of urban food activities as expression of alternative food production, and as discussed in relation to the organisations Permablitz, Urban Orchard and Food Connect, is 'small, slow and shared'. All three organisations are relatively new, innovative and popular. Each example, explored in what follows, illuminates a different aspect of the alternative food system: Permablitz tackles production; Urban Orchard is concerned with waste; and Food Connect is about distribution. ${ }^{4}$ They vary in size, scope and produce, yet all are community based and function primarily to address social and environmental concerns.

Permablitz is a grassroots-led, community volunteer project committed to improving the sustainability of cities through the creation of edible landscapes. Launched in 2006, Permablitz originally derives from the reality television show, Backyard Blitz, where backyards were transformed into gardens using 'permaculture', the sustainable, ethical design system established by David Holmgren and Bill Mollison. Working in a group, volunteers share their permaculture skills to transform residential properties into organic, food producing landscapes by integrating resources such as water, energy, waste, shelter, community, economy and governance to close the energy loop. Currently most suburban blocks produce little and consume a lot of resources, but Permablitz aims to reverse this trend by advocating for stronger, local community networks (Kizilos). Permablitz also offers health and economic advantages as people eat the seasonal fruit and vegetables they grow. Asha BeeAbraham expressed her anticipation of an upcoming blitz: 'I'm mostly looking forward to being able to wander around my garden and just bite at random plants' (cited in Smith).

The Urban Orchard project was established in 2004 at CERES in East Brunswick. It differs from older forms of exchange in that it is specifically designed for purposes of food exchange and is organised by people concerned about food security, sustainability, public health and community building (Jackson). The project initially focused on exchanging unused fruit from residents' homes with neighbours in the inner northern suburbs and has since spread to sharing

4 Food Connect did not originate in Melbourne, as is the case for the other two studies, but it is included in analysis as it was often referred to at Melbourne food movement events in 2008 and has since been established at CERES. 
vegetables, herbs, knowledge and ideas with the local community, endorsing self-reliance while reflecting the seasons, diversity and food cycle (http://www. ceres.org.au/node/114).

Food Connect is defined by founder, Robert Pekin, as 'a local and fair trading company, using a business model to address an environmental and social need' (cited in 'Funding') that is based on the Community Supported Agriculture model. Established in 2004 in Brisbane, it connects urban consumers with rural farmers to distribute fresh, predominantly organic, seasonal and affordable produce. Food Connect accepts all standards of food from farmers, packs it into boxes in their central warehouse and delivers the produce to 'City Cousins' delivery points across the city. Food Connect aims to pay farmers a fair price, supporting them to stay on their farms while benefiting the environment. Food Connect does not represent a non-commercial AFN model, but in its alternative approach to the distribution of surplus and other aspects, it embraces the characteristics of 'small, slow and shared' while further illustrating the diversity of non-capitalist alternatives.

\section{Small}

One feature of these grassroots initiatives is that they are 'small': small in number, short in supply chain, and simple in their structure and technologies. Permablitzes - free gardening workshops open to the public-exemplify the characteristic of 'small'. Although each chapter reaches a significant number of people over time, the actual size of each event is quite small. For example, two or more designers are involved to organise materials, the day's timetable and to facilitate the blitz, while the number of volunteers at an event depends on the property size but is usually capped at between 20 and 40 people. Likewise, an Urban Orchard event ranges from only one to a few people as the 'swap table' caters to an audience averaging 25 to 50 people. Food Connect is the largest of the three initiatives. In 2008, there were 40 paid staff at their Brisbane warehouse, a client base of approximately 1500 active consumers and 70 city cousins distributing 900 to 1000 boxes a week (Cameron and Gerrard).

By remaining small, each group remains engaged with their local community and their environmental needs, while providing fresh, seasonal foods. They also reduce energy consumption by not transporting produce long distances. Each case study organisation, as an example of an AFN, identifies 'local' as a key concept, embedding meanings, values and trust through proximate placebased relations of 'product-in-place' or 'process-in-place' (Renting, Marsden and Banks). Such local boundaries are important in that they tie specific food products or processes to specific regions and in doing so reinscribe a specific sense of place, for 'a place without boundaries is not a place' (Pascual-de-Sans 
351). For Permablitz, the boundaries are foremost residential yards or any other unused space fit for food production that serves as a dual site of production and consumption. For Urban Orchard, the harvest is conducted in the private spaces of an urban neighbourhood while exchange is public and kept close to production. Food Connect, on the other hand, has the most stringent parameters. Produce is collected from within a five hour radius, held together over this distance by transport, a business model and shared values, further complemented by social interaction at City Cousin nodes, farm visits, and by phoning the farmer. These boundaries encompass not just the 'local' but also the extent of the supply chain itself, often called 'Short Food Supply Chains' (SFSCs). SFSCs are tied to the local, shorten producer-consumer relations and short-circuit long, anonymous supply chains, and are assumed to capture local economic returns. SFSCs are the result of an active construction of networks, where the role of the relationship between producers and consumers is to construct value and meaning (Renting, Marsden and Banks).

In terms of simplicity, each initiative is relatively easy to establish and manage by using basic, inexpensive and accessible technologies. All projects require a web presence and a communication strategy, such as an email list, to organise and promote activities. Permablitz requires shared tools, Urban Orchard a table, while Food Connect needs warehouse space and locations for food deliveries in addition to transport, labour and food packaging. Costs remain negligible as organisers draw on no- or low- cost resources such as the internet or recycled materials. Work spaces are often shared, as members' houses, community centres or schools become delivery and drop-off points. Also, because there is no corporate ownership for these models, organisations can be easily replicated and reproduced by new groups elsewhere. ${ }^{5}$ The primary goal of such networks is, rather than focused on profit-making, to benefit groups and locales with each initiative aiming to stay small and simple to maintain integrity and be easily transferred.

\section{Slow}

Although the organisations represented here are small, they remain costly in terms of time. However, 'time' in these examples is associated not with cost efficiency but with quality produce and environmental ethics and in a way that compares to the ethos of the Slow Food and Slow Cities movements. The slowing of time in the Slow Food movement counters the loss of local distinctiveness as it relates to food, conviviality and sense of place, while Slow Cities aims to protect and enhance urban livability and quality of life, both of which are threatened

5 Although no-one 'owns' the initiatives, it is common for local leaders to establish the initial connections and to mobilise the community. 
by the fast pace of modern, corporate-centered, urban lifestyles (Mayer and Knox). As stated on a Slow Food website, key goals are: 'to counteract fast food and fast life, the disappearance of local food traditions and people's dwindling interest in the food they eat, where it comes from, how it tastes and how our food choices affect the rest of the world' ('What is Slow Food?'). So too do many grassroots food initiatives signify resistance as they re-ascribe values within spaces of contested meanings by re-connecting planet, people, place and plate in new ways. Food Connect's shortlisting in the Best Slow Money Enterprise in North America awards demonstrates its important place as advocate for cultural, ecological and economic diversity in an economy based on healthy people in healthy places (http://www.slowmoneyalliance.org/).

Likewise, the 'quality turn' within AFNs represents the knowledge gained from gardeners and farmers exchanged through interpersonal relations and localised tacit knowledge that emphasises the quality of the process and the produce. It is a place-based, ecological rationale that realigns nature, quality, locale, producers and consumers (Feagan). The moral economy of AFNs then represents a double movement that disconnects one from the current system, to critically reflect on established truths, to form new moral understandings for (re)connection (Goodman).

The simplicity of these activities incorporates ethical values into citizens' everyday routines. As expressed by Permablitz co-founder, Adam Grubb (cited in Fawcett 20), Permablitz design emphasises a laid-back existence: 'We're basically lazy gardeners. ... You have to be really committed to go up to the back corner, whereas here the most high-maintenance things are in between where Steve is going to collect his eggs from the chicken coop and the clothesline'. Although the quickness of a blitz seems to contradict the AFN aspect of 'slow', Grubb explains: 'Blitzing implies something fast, but it's a way of hastening our way to simpler things. It's about taking care of yourself and the environment. And, with food prices going up, it's becoming increasingly about that, too' (cited in Bounds 30).

Importantly, the case study organisations discussed here differ to the Slow Food and Slow Cities movements as they provide greater affordability and accessibility to produce, helping to address concerns that the movement is intrinsically elitist. Both Permablitz and Urban Orchard are free to attend to exchange organic resources, and Permablitzes are performed on both rental and owned properties, while Food Connect provides fresh, predominantly organic produce for twenty percent less than supermarket cost.

Costs are reduced through reciprocal practices and through reusing wasted resources found both within the food system and the city. Permablitz and Urban Orchard rely entirely on volunteer support with all participants required 
to contribute time and energy-participants' properties will be blitzed after participation on at least three events, while Urban Orchard allows products exchanged to be as small as worm castings or seeds, allowing those who make an effort to join in. Food Connect is built on an equity approach, as customers buy a share in the harvest by paying for their food four weeks in advance to guarantee an income for the farmer (even if crops fail), ensuring both farmers and workers a fair price; there are no volunteers (Cameron and Gerrard). Each initiative reuses waste and transforms it into a resource in various ways: Permablitz recognises wasted urban space as potential garden sites and uses organic matter as compost; Urban Orchard re-distributes surplus harvests; and Food Connect accepts food that would be rejected by supermarkets and has recently also included excess produce from backyard growers in its supply chain (Readfearn).

Pink identifies the creation of slow as 'alternative urban sense-scapes', revitalising urban spaces with the shared, social experience of rediscovering food. Permablitzes reinvigorate the ignored backyard, Urban Orchard attracts new faces to public parks and markets to share, taste and talk, while Food Connect reconnects country and City Cousins on communal territories of exchange. 'Slow' acknowledges that it takes time to do ethical things: to growyour-own food, to talk to your neighbours, and to live your life according to social and environmental justice principles. This temporal shift is illustrated in the case study organisations as one takes the time on the weekend to share one's knowledge and learn how to grow a new plant at a Permablitz, as one takes the time to taste and discuss an unusual fruit on offer at the Urban Orchard, and as farmers take the time to experiment with new crops thanks to the support offered by the Food Connect. In order to fully appreciate the values of a sustainable food system, in order to re-embed multiple values into one activity, simply put, one must learn to slow down.

\section{Shared}

Finally, 'shared' refers to the sharing of skills, time, space, meals, tools, responsibilities, risk, values, language and enjoyment as expressed in a range of ways by the case study organisations. Participants consider the shared worth of the food they eat and the responsibilities that consumption signifies for the producer, the consumer and the environment. For example, swappers at an Urban Orchard must assess the value of their contributions in exchange for other items while considering factors of quality and uniqueness (Jackson). Food Connect expects farmers to set their own price: 'We tell the farmers to tell us what they want to get paid so it puts the onus on them to think what are my costs? What are the environmental considerations?' (Pekin cited in Hall 14). 
Shared, grounded participation helps to overcome citizens' feelings of being overwhelmed by the complex, powerful and all-encompassing scope of the industrial food system. As recognised by British activist, Helena NorbergHodge (cited in Humphery), such forms of social networking help to address perceptions about alternative food practices as a kind of 'opting out'. Hence, by working together, people can harness the skills, resources, time and motivation to achieve more than they could alone. By experiencing graspable change in the here and now, such as by participating in an AFN, they can begin to visualise change already occurring elsewhere.

Although this article focuses primarily on the immediate, positive characteristics of AFNs it is important to note that more in-depth research is needed to ascertain the overall long term outcomes of these practices. For example, the extent of accessibility and desire to engage in such food initiatives may be influenced by issues of class, location, and/ or mobility, in addition to other factors, such as urban pollution. Class reflects certain priorities and values, influencing citizens' knowledge of, interest in, and ability to participate and commit to activities, while differences in peoples' immediate environments and transport options between the outer and inner city could also affect peoples' involvement. Questions arising from this new wave of food engagement include if and how these activities reach across the socio-economic spectrum in cities, and if they do in fact promote greater urban resilience and future contributions to food security and population health in times of climate change.

\section{Future food possibilities: pathways of transmission}

These different forms of sharing create community ties that, if harnessed correctly, can lead to established networks that can potentially yield greater influence and power, as AFNs can reproduce their meanings and values and influence other structures, thus extending into new spaces (Murdoch and Marsden). Latour asserts that structures are continually reproduced through processes of interaction that exert power in actua over others. Hence, the analysis of power becomes the study of associations that produce collective action, where success is the ability to 'colonise' the worlds of others by battling contested meanings. Hence, new meanings and values can be transported through associations from one place (such as the periphery) to influence or dominate another (such as the centre) (Murdoch and Marsden).

There is evidence that AFNs are achieving success as their knowledge, values and ethics grow richer and wider, extending across the world. According to Seyfang and Smith, innovations can produce either intrinsic or diffusion 
benefits. 'Intrinsic benefits' represent a symbolic embodiment that 'another way is possible' (594), while their contrast to mainstream behaviour reveals the inconsistencies and contradictions embedded within the traditional system. Alternatively, 'diffusion benefits' could contribute to the mainstream by influencing the uptake of new consumer behaviours, such as green consumption. Success of AFNs, and more specifically of the case study organisations, can thus be determined in two ways: by the replication of these models while maintaining the integrity of their values ('intrinsic benefits'); and by the translation of these values into the mainstream community ('diffusion benefits').

Permablitz, Urban Orchard and Food Connect have all successfully 'self-budded' to grow into new sites. The Permablitz concept has rocketed in participation since its inception with more than 100 offshoots spreading across Australia and overseas (http://www.permablitz.net/); the Urban Orchard project has sprouted multiple swap programs both in Melbourne and around Australia (Jackson); and the Brisbane Food Connect model has propagated into new cities such as Sydney, Adelaide and Melbourne (http://www.foodconnect.com.au/). In terms of numbers, Grubb estimates that, as of April 2010, 2000 individuals will have attended Permablitzes in Melbourne alone. Meanwhile, in Melbourne, the monthly Yarra Neighbourhood Orchard and the Western Urban Harvest Swap receive 25 to 50 regular attendees in addition to regular attendees at the weekly Urban Orchard at CERES (Jackson).

Evidence of diffusion benefits from the case study organisations includes positive broad media coverage and the uptake of the models by new institutions and groups. All groups have received extensive media coverage with standout publicity such as at the 'World's Biggest Eva Vegie Swap' at the 2009 Melbourne Food and Wine Festival (Jackson), Permablitz's profile story on the television program, Costa's Garden Odyssey ('Episode 3'), and Food Connect winning the Minister's Award for Climate Smart Leadership in the Queensland Sustainable Industries Awards, as first recipient of itank's Designers for Good Benefit Award, and as finalist for the Banksia Awards (Locklear). Although Permablitz seems to be subversively advocating for the transformation of pristine lawns into productive landscapes and decentralizing food production, this model is now endorsed by local councils, environmental and community groups and by the Dandenong Development Board who applied the Permablitz model to their Greater Dandenong Edible Gardens Project (Underwood). ${ }^{6}$ Food Connect have also encouraged others to take up other AFN schemes. Ray Palmer, a farmer with Food Connect says: 'We got lots of encouragement from Food Connect to start our own organic community-supported agriculture box service' (cited in Channon 13).

6 Dan Palmer, Permablitz co-founder, received a breach of duty notice from his landlord giving the tenants two weeks notice to either deconstruct their productive foodscape and restore the lawn or pay \$2100 (Kizolas). 
Diffusion benefits raise concerns about the future of AFNs in the wake of dominant capitalist forces. Mainstreaming innovation can fragment the original context in which AFNs are created, risking losing the integrity of original meanings and values and co-opting them within the capitalistic framework, as illustrated by the varied meanings of 'organic', 'sustainable', 'natural', 'green', 'local', and even 'alternative' (see Johnston, Biro and MacKendrick). Gibson-Graham recognise that diverse economies have, and continue to, exist within a world dominated by capitalism, while neoliberal strategies that attempt to subvert them include 'co-option, seduction, capture, subordination, cooperation, parasitism, symbiosis, conflict, coexistence, (and) complementarity' (71). Furthermore, Guthman believes that many of the very AFNs that strive to be different from the neoliberal economy instead reproduce neoliberal forms, spaces of governance, and mentalities. In her analysis of food politics in California, she argues that many food activists employ neoliberal concepts such as consumer choice, localism, entrepreneurialism, and self-improvement, distracting activists from larger issues of systems change, who instead focus on aspects of individual consumption and local concerns while continuing to use market mechanisms.

However, many examples cited by Guthman and by agro-food academics in general focus on AFNs that exist as divergent forms of capitalism based around food rather than as AFNs that exist outside of a dominant capitalist system. Other types of AFNs that may have greater distance from (and possibly resistance to) capitalist coercion are those that do not exist within the commercial sector. I argue that by placing AFNs within Gibson-Graham's diverse economies framework (see 71), often ignored and invisible 'nonmarket, unpaid, and noncapitalist' AFNs can instead be considered to offer possible alternative discourses of change. By maintaining their integrity and by extending the current networks of certain types of non-commodified AFNs, such as the ones described in this essay, new stronger networks featuring both intrinsic and diffusion benefits could become possible.

The grassroots initiatives discussed in this paper could be seen as a contemporary re-working of the 1960s food subcultures that ushered in organic production, cooperatives and wholefoods both in Australia and abroad (Belasco; Gaynor), whose future success depends upon the integration of new accessible technologies in a landscape of knowledge that is aware of, and sensitive to, neoliberal politics. Steel suggests a 'semi-lattice' form for emerging AFNs: a complex network of interactions that are localised, personal, flexible, multidirectional, and all of which can affect the other (310). This desire to build new networks is apparent in many AFNs. The South Australian 'Plains to Plate' Conference Declaration affirms this desire: 
The building of a just, sustainable and secure food system necessitates the convergence of diverse groups to work together. At From Plains to Plate, we have come together in recognition of our common ground. The work we do as a network of farmers, community members, health and government workers, neighbourhood organisations, teachers, academics, educators and community members in South Australia is echoed in the actions of social and environmental movements across Australia and the world. We are a global movement, an alliance across a diversity of sectors to assert the importance of the justice, sustainability, security and sovereignty of our food system.

Possible future outcomes stemming from grassroots innovation and AFNs include Food Policy Councils that push ahead consolidated food security action in municipalities (Blay-Palmer; Harper et al.); ${ }^{7}$ the Friends of the Earth Melbourne proposal to create sustainable super 'eco-markets' ; and the concept of Food Sensitive Planning and Urban Design that aims to incorporate food within the city in new ways to harness greater sustainability (VEIL and David Locke Associates). In other words, future food possibilities could form a force of change, a change in system parts, or a change in the system overall.

\section{In conclusion}

Melbourne's current food movement represents a rich tapestry of historical backyard production complemented by capitalist, institutional, and emerging alternative, innovative food practices. This new wave of civic engagement based around food is diverse in approach and participation, offering new connections to place, people and produce. The three case study organisations of Permablitz, Urban Orchard and Food Connect and their characteristics of 'small, slow and shared' offer new insights to AFN theory, as in their non-commodified and non-capitalist forms they re-position and question traditional relationships between producer and consumer, returning the 'consumer' to the status of an empowered, active citizen within a social network. Regardless of the future outcomes - be it as symbolic resistance, as contributing to green consumerism, or as networks guiding system change - these grassroots initiatives place food within the community and, in doing so, place value on the specifics of a locale or region, environmental sustainability and social equality. That these practices are reaching broader and more diverse communities suggests an emerging urban foodscape of citizen empowerment, action and hope.

7 A Food Policy Coalition was proposed by Dr Cate Burns for Melbourne in 2009. 
Ferne Edwards is a PhD student at the National Centre for Epidemiology and Population Health, Australian National University. Her articles include 'Gleaning from Gluttony: an Australian Youth Subculture confronts the ethics of waste', and 'Meals in Metropolis: mapping the urban foodscape in Melbourne, Australia'. Her doctorate investigates alternative food movements in Australia and Venezuela.

\section{Acknowledgements}

Much thanks to Dave Mercer and Jane Dixon for their comments and support. Thank you also to Kirsten Larsen and Chris Ryan for their contributions on the briefing paper, 'Social Innovations in the Food System' on which this paper is based. And thank you to all the people in the Melbourne food movement for their inclusiveness, commitment and passion.

\section{Works cited}

'Bacchus Marsh Produce Swap'. Permaculture Out West: All Things Permaculture in the Western Suburbs of Melbourne. < http://www.pow.org.au/2011/06/26/ bacchus-marsh-produce-swap $>$. Accessed 26 October 2011.

Barrett, Bernard. The Inner Suburb. The Evolution of an Industrial Area. Melbourne: Melbourne UP, 1971.

Belasco, Warren. Appetite for Change. How the Counterculture Took on the Food Industry, 1966-1988. New York: Pantheon Books, 1989.

Blay-Palmer, Alison. 'The Canadian Pioneer: The Genesis of Urban Food Policy in Toronto.' International Planning Studies 14.4 (2009): 401-416.

Bounds, Joanna. 'Cheap Thrills.' Sunday Telegraph Magazine, 29 June 2008: 30.

Buxton, Michael, Amaya Alvarex, Andrew Butt, Stephen Farrell and Danny O'Neill. Planning Sustainable Futures for Melbourne's Peri-urban Region. Summary report. Melbourne: RMIT University, 2008.

Cameron, Jenny and Josephine Gerrard. Thinking and Practising Values: Community Enterprises in the Food Sector. Newcastle: University of Newcastle, 2008.

Channon, Emma. 'Connecting with Food Producers.' Warwick Daily News, 6 April 2010: 13. 
Crittenden, Stephen. 'Food Fears. Background Briefing. ABC Radio National. 18 April 2010. <http://www.abc.net.au/rn/backgroundbriefing/stories/2010/ 2871237.htm $>$. Accessed 26 October, 2011.

'Declaration - Plains to Plate: The Future of Food in SA'. <http://futureoffoodsa. ning.com/page/declaration-1>. Accessed 26 October 2011.

Edwards, Ferne, and Dave Mercer. 'Meals in Metropolis: Mapping the Urban Foodscape in Melbourne, Australia' Local Environment 15:2 (2010): 153-168.

- et al. 'Climate change adaptation at the intersection of food and health.' Asia-Pacific Journal of Public Health 23.2 (2011): 91S-104S.

- Kirsten Larsen and Chris Ryan. Briefing Paper: Social innovations in Victorian food systems. Melbourne: Victorian Eco-Innovation Lab, University of Melbourne, unpublished draft.

Environment Victoria. Pedalling Fruit Pickers Project Kit. Melbourne: Environment Victoria, 2008.

'Episode 3.' Costa's Garden Odyssey. SBS Television. 10 September 2009.

'EventsCalendar.' MelbournePermablitz:EatingtheSuburbs - One BackyardataTime. <http://www.permablitz.net/calendar/icalrepeat.detail/2011/08/13/264/14/ permablitz-braybrook-a-maidstone-neighbourhood-house $>$. Accessed 26 October 2011.

Fawcett, Tony. 'Home-grown Makeover.' Sunday Times, 11 July 2009: 20.

Feagan, Robert. 'The Place of Food: Mapping out the 'Local' in Local Food Systems.' Progress in Human Geography 31.1 (2007): 23-42.

Foodconnect. <http://brisbane.foodconnect.com.au/>. Accessed 26 October 2011.

Friends of the Earth Adelaide. Food Convergence Declaration. Adelaide: UniSA, 2010 .

Friends of the Earth Melbourne. Eco Market Briefing Paper-A Revolution in Sustainable Shopping. Melbourne: Friends of the Earth Melbourne, 2008.

'Funding reality check for social efforts' ABC Rural. 27 April $2010<\mathrm{http}$ :/ www.abc.net.au/rural/news/content/201004/s2883951.htm>. Accessed 26 October 2011.

Gallagher, Heather. 'Backyard Boom in Chooks.' Northcote Leader, 14 November 2007, 1 ed. 
Gaynor, Andrea. Harvest of the Suburbs. An Environmental History of Growing Food in Australian Cities. Perth: U of Western Australia P, 2006.

Gibson-Graham, J.K. A Postcapitalist Politics. Minneapolis: U of Minnesota, 2006

Goodman, David. 'Place and Space in Alternative Food Networks Connecting Production and Consumption.' Environment, Politics and Developoment Working Paper Series, Department of Geography, King's College London, 2009.

Gott, Beth and John Conran. Victorian Koorie plants: Some Plants Used by Victorian Koories for Food, Fibre, Medicines and Implements. Hamilton, Victoria: Yangennanock Women's Group, 1991.

Guthman, Julie. 'Neoliberalism and the Making of Food Politics in California.' Geoforum 39 (2006): 1171-1183.

Halkett, Ian. The Quarter Acre Block. The Use of Suburban Gardens. Canberra: Institute of Urban Studies, 1976.

Hall, Wendy. 'Growth sector.' Brisbane City News, 7 May 2009: 14.

Harper, Alethea, Annie Shattuck, Eric Holt-Gimenez, Alison Alkon and Frances Lambrick.Food Policy Councils: Lessons Learned. 2009. <http://www. foodfirst.org/en/foodpolicycouncils-lessons > . Accessed 26 October 2011.

Hayes, Patrick. 'The "Sharing Backyards" Idea.' < http://www.cityfarmer.org/ sharingBackyards.html>. Accessed 26 October 2011.

Head, Lesley $\mathrm{M}$ and P.A Muir. Backyard. Nature and Culture in Suburban Australia. Wollongong: U of Wollongong P, 2007.

Holmes, Katie, Susan Martin and Kylie Mirmohamadi. Reading the Garden. Melbourne: Melbourne UP, 2008.

Hujber, D. 'Barriers and Challenges of "Grow Your Own" Food Schemes in Melbourne.' Budapest: Central European University, 2008.

Humphery, Kim. Excess. Anti-Consumerism in the West. Cambridge: Polity, 2010.

Jackson, Sue. 'I'll Raise You Six Granny Smiths.' 24 March 2010. <http:// newmatilda.com/2010/03/24/ill-raise-you-six-granny-smiths $>$. Accessed 26 October 2011.

Johnston, Josee, Andrew Biro, and Norah MacKendrick. 'Lost in the Supermarket: The Corporate-Organic Foodscape and the Struggle for Food Democracy.' Antipode: A Radical Journal of Geography 41.3 (2009): 509-532. 
Kizilos, Katherine. 'Blitzing the 'burbs'. The Age, 17 July 2007. <http://www. theage.com.au/articles/2007/07/16/1184559700758.html>. Accessed 26 October 2011.

Latour, Bruno. 'The Powers of Association.' Power, Action, Belief: A New Sociology of Knowledge? Ed. John Law. London: Routledge \& Kegan Paul, 1986. 264-280.

Locklear, Rob. 'Food Co-op Connects Paddock with Plate'. The Queensland Times, 1 July 2009.

Low Choy, Darryl, Cassara Sutherland, Brendan Gleeson, Jago Dodson and Neil Sipe.Change and Continuity in Peri-Urban Australia: Peri-Urban Futures and Sustainable Development. Brisbane: Griffith University, 2008.

Mayer, Heike, and Paul L. Knox. 'Slow Cities: Sustainable Places in a Fast World.' Journal of Urban Affairs 28.4 (2006): 321-334.

Moreland Community Health Service. Grow and Share Summary. Melbourne: Moreland Community Health Service, 2008.

Mullins, Patrick. 'Theoretical Perspectives on Australian Urbanisation: 1. Material Components in the Reproduction of Australian Labour Power.' Australian and New Zealand Journal of Sociology 17.1 (1981): 65-76.

Murdoch, Jonathan and Terry Marsden. 'The Spatialization of Politics: Local and National Actor-Spaces in Environmental Conflict.' Transactions of the Institute of British Geographers 20.3 (1995): 368-380.

Pascual-de-Sans, Angels. 'Sense of Place and Migration Histories Idiotopy and Idotope.' Area 36 (2004): 348-357.

Patel, Raj. The Value of Nothing. London: Portobello Books, 2009.

Pink, Sarah. 'Sensing CittaSlow: Slow living and the Constitution of the Sensory City.' The Senses and Society 2.1 (2007): 59-77.

Pollan, Michael. 'Our Decrepit Food Factories.' New York Times, 16 December 2007.

Readfearn, Graham. 'Revolutionaries Revel in Home-Grown Vegies.' The Courier Mail, 22 January 2010.

Renting, Henk, Terry Marsden and Jo Banks. 'Understanding Alternative Food Networks: Exploring the Role of Short Food Supply Chains in Rural Development.' Environment and Planning A 35 (2003): 393-411. 
Seyfang, Gill and Adrian Smith. 'Grassroots Innovations for Sustainable Development: Towards a New Research and Policy Agenda.' Environmental Politics 16.4 (2007): 584-603.

Sixty Minutes. 'Backyard Revolution'. 3 April 2009. <http://sixtyminutes. ninemsn.com.au/article.aspx?id=797223>. Accessed 26 October 2011.

Slow Food. Slow Food International. 2 April 2010. < http://www.slowfood. com>. Accessed 26 October 2011.

Smith, Lou. 'Permablitzing the suburbs.' (2006). 12 December 2008. <http:// www.permablitz.net/index2.php?option=com_content\&task $>$. Accessed 26 October 2011.

Sola, Nelly and Beth Gott. Koorie Plants, Koorie People: Traditional Aboriginal Food, Fibre and Healing Plants of Victoria. Melbourne: Koorie Heritage Trust, 1992.

Steel, Carolyn. Hungry City. How Food Shapes our Lives. London: Chatto \& Windus, 2008.

Underwood, B. 'The Greater Dandenong Edible Gardens Project: An Innovative Approach to Partnership Based Community Building.' International Cities, Town Centres \& Communities Conference, 2008.

VEIL, and David Locke Associates. A Conceptual Framework for Food Sensitive Planning and Urban Design (FSPUD). Melbourne: Victorian Heart Foundation, 2010.

'What is slow food?' Slow Food Ireland. <http://www.slowfoodireland.com/ index.php/slow-food/what-is-slow-food.html?q=\%2Findex.php \% 2Fslowfood $\% 2$ Fwhat-is-slow-food.html\&showall=1>. Accessed 26 October 2011. 